\title{
Wastewater Treatment: An Overview
}

\author{
Grégorio Crini and Eric Lichtfouse
}

\section{Contents}

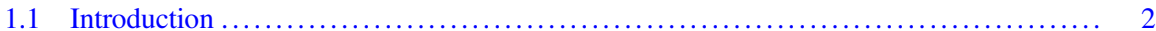

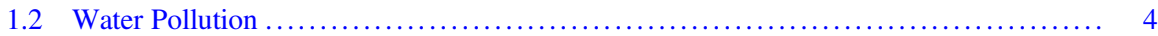

1.2.1 Contamination and Contaminants ................................... 4

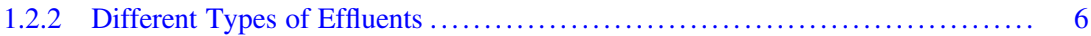

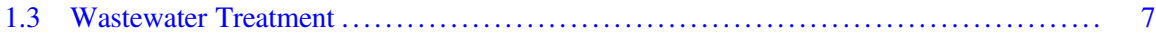

1.3.1 General Scheme of Wastewater Treatment ........................... 7

1.3.2 Technologies Available for Contaminant Removal ..................... 8

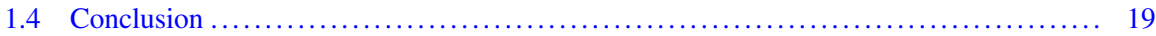

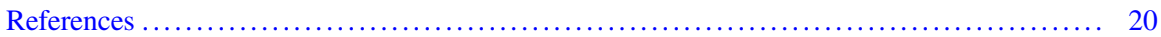

\begin{abstract}
During the last 30 years, environmental issues, especially concerning the chemical and biological contamination of water, have become a major concern for both society and public authorities, but more importantly, for the whole industrial world. Any activities whether domestic or agricultural but also industrial produce wastewaters or effluents containing undesirable contaminants which can also be toxic. In this context, a constant effort must be made to protect water resources. In general, conventional wastewater treatment consists of a combination of physical, chemical, and biological processes and operations to remove insoluble particles and soluble contaminants from effluents. This chapter briefly discusses the different types of effluents, gives a general scheme of wastewater treatment, and describes the advantages and disadvantages of technologies available.
\end{abstract}

\footnotetext{
G. Crini $(\bowtie)$

Laboratoire Chrono-environnement, UMR 6249, UFR Sciences et Techniques, Université Bourgogne Franche-Comté, Besançon, France

e-mail: gregorio.crini@univ-fcomte.fr

E. Lichtfouse

CEREGE, Aix Marseille Univ, CNRS, IRD, INRA, Coll France, Aix-en-Provence, France e-mail: eric.lichtfouse@inra.fr
} 


\section{Abbreviations}

AC Activated carbons

AOP Advanced oxidation processes

AOX Adsorbable organic halogen

BAS Biological activated sludge

BOD Biochemical oxygen demand

CAA Commercial activated alumina

CAC Commercial activated carbons

COD Chemical oxygen demand

CW Constructed wetlands

CWAO Catalytic wet air oxidation

D Dialysis

DPS Dangerous priority substances

E Electrolysis

EC Electro-coagulation

ED Electrodialysis

EED Electroelectro-dialysis

EF Electro-flocculation

ELM Emulsion liquid membranes

ICP Inductively coupled plasma

MF Microfiltration

MVP Membrane pervaporation

NF Nanofiltration

PAH Polycyclic aromatic hydrocarbons

PCB Polychlorobiphenyls

PS Priority substances

RS Reverse osmosis

SLM Supported liquid membranes

SS Suspended solids

TOC Total organic carbon

TOD Total oxygen demand

UF Ultrafiltration

VOC Volatile organic compounds

WAO Non catalytic wet air oxidation

WFD Water Framework Directive

\subsection{Introduction}

Actually, water pollution by chemicals has become a major source of concern and a priority for both society and public authorities, but more importantly, for the whole industrial world (Sonune and Ghate 2004; Crini 2005; Cox et al. 2007; 
Sharma 2015; Rathoure and Dhatwalia 2016). What is water pollution? Water pollution can be defined in many ways. Pollution of water occurs when one or more substances that will modify the water in negative fashion are discharged in it. These substances can cause problems for people, animals and their habitats and also for the environment. There are various classifications of water pollution (Morin-Crini and Crini 2017). The two chief sources can be seen as point and non-point. The first refers to the pollutants that belong to a single source such as emissions from industries into the water, and the second on the other hand means pollutants emitted from multiple sources.

The causes of water pollution are multiple: industrial wastes, mining activities, sewage and waste water, pesticides and chemical fertilizers, energy use, radioactive waste, urban development, etc. The very fact that water is used means that it will become polluted: any activities whether domestic or agricultural but also industrial produce effluent containing undesirable pollutants which can also be toxic. In this context, a constant effort must be made to protect water resources (Khalaf 2016; Rathoure and Dhatwalia 2016; Morin-Crini and Crini 2017).

The legislation covering liquid industrial effluent is becoming stricter, especially in the more developed countries, and imposes the treatment of any wastewater before it is released into the environment. Since the end of the 1970s, in Europe, the directives are increasingly severe and zero rejection is being sought by 2020 . Currently, the European policy on water results from the Water Framework Directive (WFD) of 2000 which establishes guidelines for the protection of surface water, underground water, and coastal water in Europe (Morin-Crini and Crini 2017).

The WFD also classified chemicals into two main lists of priority substances. The first, the "Black List", involves dangerous priority substances (DPS) considered to be persistent, highly toxic or to lead to bioaccumulation. The second list, the "Grey List", gathers priority substances (PS) presenting a significant risk for the environment. The selection of these substances can either be based on individual substances of families of substances (e.g. metals, chlorobenzenes, alkylphenols, etc.) or on the basis of the industrial sector (e.g. agro-food industry, chemicals industry, metalfinishing sector, etc.). Currently, Europe is now asking industrials to innovate to reduce and/or eliminate the release of DPS and PS chemicals in their wastewaters.

Moreover, recycling wastewater is starting to receive active attention from industry in the context of sustainable development (e.g. protection of the environment, developing concepts of "green chemistry", use of renewable resources), improved water management (recycling of waste water) and also health concerns (Kentish and Stevens 2001; Cox et al. 2007; Sharma and Sanghi 2012; Khalaf 2016; Rathoure and Dhatwalia 2016; Morin-Crini and Crini 2017). Thus, for the industrial world, the treatment of effluents has become a priority.

During the past three decades, several physical, chemical and biological technologies have been reported such as flotation, precipitation, oxidation, solvent extraction, evaporation, carbon adsorption, ion-exchange, membrane filtration, electrochemistry, biodegradation, and phytoremediation (Berefield et al. 1982; Liu and Liptak 2000; Henze 2001; Harvey et al. 2002; Chen 2004; Forgacs et al. 2004; Anjaneyulu et al. 2005; Crini and Badot 2007; Cox et al. 2007; Hai et al. 2007; 
Barakat 2011; Rathoure and Dhatwalia 2016; Morin-Crini and Crini 2017). Which is the best method? There is no direct answer to this question because each treatment has its own advantages and constraints not only in terms of cost but also in terms of efficiency, feasibility, and environmental impact. In general, elimination of pollutants is done by both physical, chemical and biological means. At the present time, there is no single method capable of adequate treatment, mainly due to the complex nature of industrial effluents. In practice, a combination of different methods is often used to achieve the desired water quality in the most economical way.

After a brief discussion on the main contaminants/pollutants and the different types of effluents, this chapter proposes a general scheme of wastewater treatment and presents the advantages and disadvantages of different individual techniques used.

\subsection{Water Pollution}

\subsubsection{Contamination and Contaminants}

Contamination/Pollution arises from all sectors of human activity (i.e. domestic, industrial and agricultural), and is not only due to natural (petroleum, minerals, etc.) and anthropogenic causes (e.g. sewage treatment sludge or persistent organic pollutants produced by the incineration of waste) but also, and especially, to synthetic substances produced by chemical industries (e.g. dyes, fertilizers, pesticides, and so on). The terms contamination/pollution and contaminant/pollutant are often used in relation to subjects like environment, food and medicine (Amiard 2011; Rathoure and Dhatwalia 2016). Both contaminant and pollutant refer to undesirable or unwanted substances. Pollutant refers to a harmful substance but contaminant is not necessarily harmful since contamination refers simply to the presence of a chemical substance where it should not be. This means that all pollutants are contaminants, but not all contaminants are pollutants. In this chapter, both these terms were used.

A chemical pollutant is a substance toxic for flora and fauna, and for humanity, and present at concentrations such that, in nature, it has repercussions on the environment and on health in general. Pollutants can be categorized according to the sources they are derived from, such as water pollutants, soil pollutants, air pollutants or noise pollutants (Crini and Badot 2007). Examples of pollutants known to the public and found in waters are numerous and various. The list includes nitrates, phosphates, detergents, pesticides and other crop sprays, chlorinated solvents but also metals (e.g. lead, mercury, chromium, cadmium, arsenic), dyes, organics (benzene, bisphenol A...), mineral derivatives (especially arsenic and cyanides) and microorganisms (e.g. bacteria, virus). Others are less well known 
but are considered to be high on the list of dangerous substances: volatile organic compounds (VOC), polycyclic aromatic hydrocarbons (PAH), polychlorobiphenyls (PCB), bromine-containing flame-retardants, phthalates, and many more (Liu and Liptak 2000; Sonune and Ghate 2004; Sharma and Sanghi 2012).

One way of measuring the quality of water is to take samples of this water and measure the concentrations of different substances that it contains, using analytical techniques such as, for instance, inductively coupled plasma (ICP) for metals, and/or determine chemical indicators or global parameters (Morin-Crini and Crini 2017). Typically, water quality is determined by comparing the physical and chemical characteristics of a sample with water quality guidelines or standards based on scientifically assessed acceptable levels of toxicity to either humans or aquatic organisms. Biological indicators using living organism such as fish can be also used. From the wastewater treatment point of view, it is also important to list the exact chemical composition of the effluents to be treated (Liu and Liptak 2000; Lacorte et al. 2003; Pokhrel and Viraraghavan 2004; Sharma 2015; Druart et al. 2016). Indeed, before any actions can be taken to reduce and/or eliminate any chemicals, it is necessary to identify all the dissolved substances in the effluents qualitatively and quantitatively using. However, a real effluent can be also a non-uniform mixture, colored and/or smelly, contain suspended solids (SS), immiscible liquids (e.g. oils, fats, hydrocarbons), soluble and/or biodegradable molecules, substances that can give waters redox potential, acidity, or pathogenicity problems (Anjaneyulu et al. 2005; Crini and Badot 2010; Sharma and Sanghi 2012; Sharma 2015; Morin-Crini and Crini 2017). In this case, wastewater quality can then be defined by physical, chemical and biological characteristics or general parameters (Cooper 1993; Liu and Liptak 2000; Crini and Badot 2007). Physical parameters include color, temperature, solids, turbidity, odor, oil and grease. Solids can be further classified into suspended and dissolved substances as well as organic and inorganic fractions. Chemical parameters associated with the organic content of industrial wastewater include the chemical oxygen demand (COD), biochemical oxygen demand (BOD), total organic carbon (TOC), and total oxygen demand (TOD). Inorganic chemical parameters include salinity, $\mathrm{pH}$ (acidity, alkalinity), metals, chlorides, sulfates, nitrogen, phosphorus, etc. Bacteriological parameters include coliforms, fecal coliforms, specific pathogens, and viruses. Recent books can be consulted on these topics (Sharma and Sanghi 2012; Sharma 2015; Khalaf 2016; Rathoure and Dhatwalia 2016; Morin-Crini and Crini 2017).

Recently, Druart et al. (2016) investigated the chemical composition of discharge waters from a metal-finishing industry sampled over a three-month period. All these samples respected the regulatory standards. Twenty-on water parameters and 164 substances were monitored, among them organic and metallic compounds. The results indicated, that, on average, 52 substances were found with a high variability, both qualitative and quantitative. Inorganics such as calcium, sodium and chloride were present at concentrations close to $\mathrm{g} / \mathrm{L}$ and metals higher than $\mathrm{mg} / \mathrm{L}$. Organics were detected at trace levels $(\mathrm{ng} / \mathrm{L}$ of $\mu \mathrm{g} / \mathrm{L})$. 


\subsubsection{Different Types of Effluents}

There are various sources of water contamination (e.g. households, industry, mines, infiltration) but one of the greatest remains its large scale use by industry (Anjaneyulu et al. 2005; Hai et al. 2007). Four categories of water are generally distinguished: (1) rainwater (runoff from impermeable surfaces), (2) domestic wastewater, (3) agricultural water and (4) industrial wastewaters (Crini and Badot 2007). The last group can be subdivided into cooling water, washing effluent (of variable composition), and manufacturing or process water (biodegradable and/or potentially toxic). In general, process waters (i.e. wastewaters or effluents) pose the greatest problems. Wastewaters differ significantly from drinking water sources (usually rivers, lakes, or reservoirs) in one important way: the contaminant levels in most drinking water sources are quite low as compared with contaminant levels in wastewaters derived from industrial-type activities (Cooney 1999). However, their toxicity depends, of course, on their composition, which in turn depends on their industrial origin.

It can be noted that some effluents such as from surface treatment or cokeproduction plants are serious polluters whereas the effluent from other sectors such as the agro-food industry (including dairies, sugar mills and fruit and vegetable processing units) may be heavily loaded but the substances it contains are easily biodegradable and even recyclable. Pollution issues have a strong impact on the population. Colored effluent, for instance from pulp and paper mills or from textile mills, has a strong visual impact due to its color and is perceived by the public as an indication of the presence of dangerous pollution - however toxic the coloring actually is (Lacorte et al. 2003; Pokhrel and Viraraghavan 2004; Forgacs et al. 2004; Rana et al. 2004; Anjaneyulu et al. 2005; Crini 2005; Hai et al. 2007; Wojnárovits and Takács 2008). Colored effluent can lead to nature protection associations or other stakeholders in the water bodies suing the parties responsible. In addition, it is known that paper-mill wastewater contains nutrient elements that can lead to eutrophication and thus to a heavy organic load for the aquatic environment due to the proliferation of algae at the expense of other aquatic species (Lacorte et al. 2003; Rana et al. 2004). Effluent with high levels of heavy metals from surface treatment industries is also a serious source of toxicity for aquatic ecosystems, again creating worries for the population (Rana et al. 2004; Anjaneyulu et al. 2005; MorinCrini and Crini 2017).

The industrial sectors of agro-food, textiles, pulp industry and surface-treatment industries are today considered to be the four largest consumers of water and the most polluting, in spite of the considerable effort made to clean up the processes over the last 30 years. These activities are all energy- and water-consuming as well as highly chemically polluting. The problems encountered during wastewater treatment are generally very complex as the effluent contains pollutants of various types depending on its origin. So, there are different types of effluent to treat, each with its own characteristics requiring specific treatment processes. 


\subsection{Wastewater Treatment}

\subsubsection{General Scheme of Wastewater Treatment}

When water is polluted and decontamination becomes necessary, the best purification approach should be chosen to reach the decontamination objectives (as established by legislation). A purification process generally consists of five successive steps as described in Fig. 1.1: (1) preliminary treatment or pre-treatment (physical and mechanical); (2) primary treatment (physicochemical and chemical); (3) secondary treatment or purification (chemical \& biological); (4) tertiary or final treatment (physical and chemical); and (5) treatment of the sludge formed (supervised tipping, recycling or incineration). In general, the first two steps are gathered under the notion of pre-treatment or preliminary step, depending on the situation (Anjaneyulu et al. 2005; Crini and Badot 2007, 2010).

Pre-treatment consists of eliminating the (floating) solid particles and all suspended substances from the effluent. This pre-treatment stage, which can be carried out using mechanical or physical means is indispensable, before envisaging secondary treatment because particulate pollution (e.g. SS, colloids, fats, etc.) will hinder later treatment, make it less efficient or damage the decontamination equipment. Primary chemical treatment such as oxidation for cyanide destruction and $\mathrm{Cr}(\mathrm{VI})$ reduction, $\mathrm{pH}$ adjustment, pre-reduction of a high organic load may also be required. For instance effluent from paper mills contains abundant SS such as fibres, fillers and other solids (Pokhrel and Viraraghavan 2004; Anjaneyulu et al. 2005; Sharma 2015). Effluents from textile mills have a very variable $\mathrm{pH}$ although it is often alkaline, containing a high organic

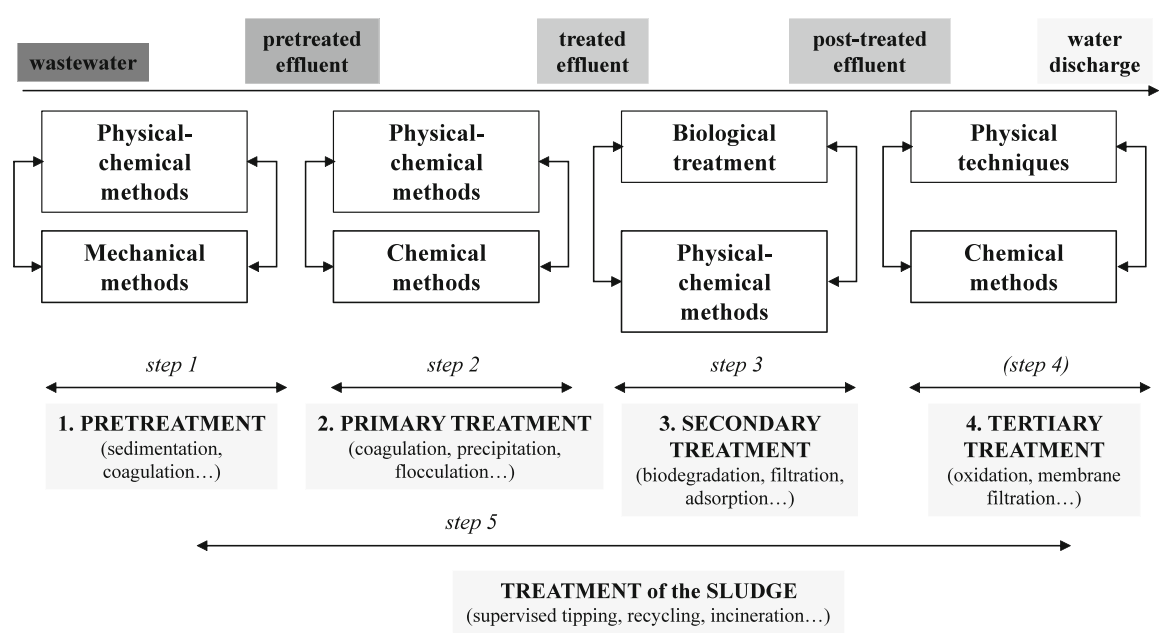

Fig. 1.1 Overview of the main processes for the decontamination of contaminated industrial wastewaters 
load. It is therefore indispensable to pre-treat these effluents before considering secondary treatment. However, these treatments alone are, in many cases, incapable of meeting the legislation requirements.

Before its discharge into the environment or its reuse, the pre-treated effluent must undergo secondary purification treatment using the most appropriate of the biological, physical or chemical techniques available to remove the chemical pollution. In certain cases, a final or tertiary treatment (step 4 in Fig. 1.1) can also be required to remove the remaining pollutants or the molecules produced during the secondary purification (e.g. the removal of salts produced by the mineralization of organic matter). However, the use of tertiary treatment in Europe is limited, though it may be necessary in the future if new restrictions are applied. The main tertiary treatments employed to date at a few industrial sites are adsorption using activated carbons (AC), ion-exchange, membrane filtration (ultrafiltration, reverse osmosis), advanced oxidation, and constructed wetlands (CW). In Europe, most of the $\mathrm{CW}$ are applied for domestic sewage and municipal wastewater treatment. However, the diversity of $\mathrm{CW}$ configurations makes them versatile for implementation to treat industrial effluents (e.g. tannery wastewater, pulp and paper post-treated effluents).

\subsubsection{Technologies Available for Contaminant Removal}

In general, conventional wastewater treatment consists of a combination of physical, chemical, and biological processes and operations to remove solids including colloids, organic matter, nutrients, soluble contaminants (metals, organics...) etc. from effluents. A multitude of techniques classified in conventional methods, established recovery processes and emerging removal methods can be used (Fig. 1.2). Table 1.1 lists the advantages and disadvantages of different individual techniques (Berefield et al. 1982; Henze 2001; Sonune and Ghate 2004; Chen 2004; Pokhrel and

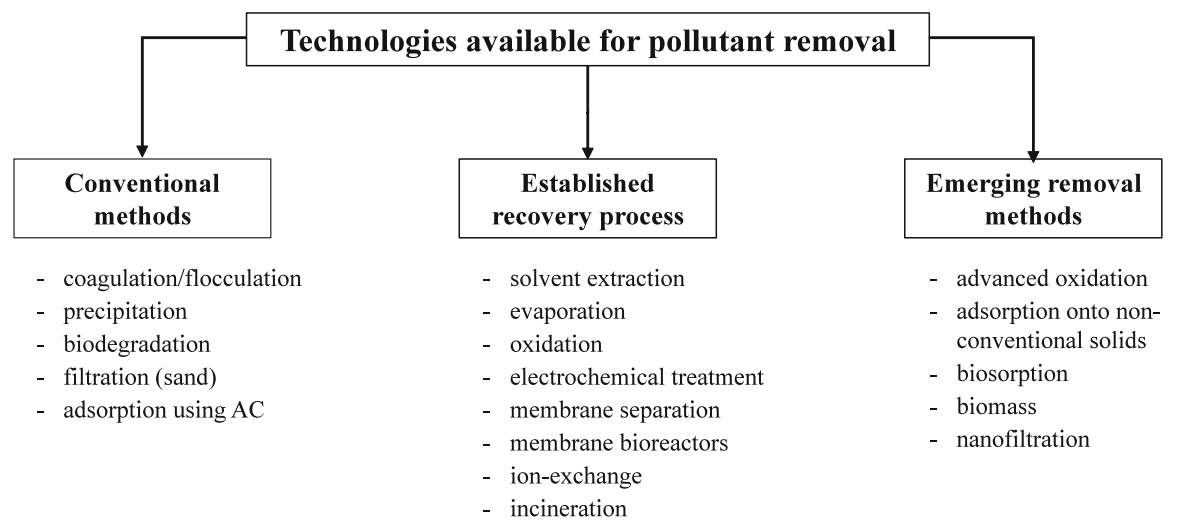

Fig. 1.2 Classification of technologies available for pollutant removal and examples of techniques 
Table 1.1 Advantages and disadvantages of the main conventional methods used for the treatment of polluted industrial wastewater

\begin{tabular}{|c|c|c|c|}
\hline Process & $\begin{array}{l}\text { Main } \\
\text { characteristic(s) }\end{array}$ & Advantages & Disadvantages \\
\hline \multirow[t]{7}{*}{$\begin{array}{l}\text { Chemical } \\
\text { precipitation }\end{array}$} & \multirow{7}{*}{$\begin{array}{l}\text { Uptake of the } \\
\text { pollutants and } \\
\text { separation of the } \\
\text { products formed }\end{array}$} & $\begin{array}{l}\text { Technological simple } \\
\text { (simple equipment) }\end{array}$ & $\begin{array}{l}\text { Chemical consumption } \\
\text { (lime, oxidants, } \mathrm{H}_{2} \mathrm{~S} \ldots \text {...) }\end{array}$ \\
\hline & & $\begin{array}{l}\text { Integrated physicochemi- } \\
\text { cal process }\end{array}$ & $\begin{array}{l}\text { Physicochemical moni- } \\
\text { toring of the effluent }(\mathrm{pH})\end{array}$ \\
\hline & & $\begin{array}{l}\text { Both economically advan- } \\
\text { tageous and efficient }\end{array}$ & $\begin{array}{l}\text { Ineffective in removal of } \\
\text { the metal ions at low } \\
\text { concentration }\end{array}$ \\
\hline & & $\begin{array}{l}\text { Adapted to high pollutant } \\
\text { loads }\end{array}$ & $\begin{array}{l}\text { Requires an oxidation } \\
\text { step if the metals are } \\
\text { complexed }\end{array}$ \\
\hline & & $\begin{array}{l}\text { Very efficient for metals } \\
\text { and fluoride elimination }\end{array}$ & \multirow{3}{*}{$\begin{array}{l}\text { High sludge production, } \\
\text { handling and disposal } \\
\text { problems (management, } \\
\text { treatment, cost) }\end{array}$} \\
\hline & & Not metal selective & \\
\hline & & $\begin{array}{l}\text { Significant reduction of } \\
\text { the COD }\end{array}$ & \\
\hline \multirow[t]{10}{*}{$\begin{array}{l}\text { Coagulation/ } \\
\text { flocculation }\end{array}$} & \multirow[t]{10}{*}{$\begin{array}{l}\text { Uptake of the } \\
\text { pollutants and } \\
\text { separation of the } \\
\text { products formed }\end{array}$} & Process simplicity & $\begin{array}{l}\text { Requires adjunction of } \\
\text { non-reusable chemicals } \\
\text { (coagulants, flocculants, } \\
\text { aid-chemicals) }\end{array}$ \\
\hline & & $\begin{array}{l}\text { Integrated physicochemi- } \\
\text { cal process }\end{array}$ & $\begin{array}{l}\text { Physicochemical moni- } \\
\text { toring of the effluent }(\mathrm{pH})\end{array}$ \\
\hline & & $\begin{array}{l}\text { A large range of chemicals } \\
\text { is available commercially }\end{array}$ & $\begin{array}{l}\text { Increased sludge volume } \\
\text { generation (management, } \\
\text { treatment, cost) }\end{array}$ \\
\hline & & Inexpensive capital cost & \multirow[t]{7}{*}{ Low removal of arsenic } \\
\hline & & $\begin{array}{l}\text { Very efficient for SS and } \\
\text { colloidal particles }\end{array}$ & \\
\hline & & $\begin{array}{l}\text { Good sludge settling and } \\
\text { dewatering characteristics }\end{array}$ & \\
\hline & & $\begin{array}{l}\text { Significant reduction of } \\
\text { the COD and BOD }\end{array}$ & \\
\hline & & $\begin{array}{l}\text { Interesting reduction of } \\
\text { TOX and AOX (pulp and } \\
\text { paper industry) }\end{array}$ & \\
\hline & & $\begin{array}{l}\text { Bacterial inactivation } \\
\text { capability }\end{array}$ & \\
\hline & & $\begin{array}{l}\text { Rapid and efficient for } \\
\text { insoluble contaminants } \\
\text { (pigments...) removal }\end{array}$ & \\
\hline Flotation & \multirow[t]{3}{*}{$\begin{array}{l}\text { Separation } \\
\text { process }\end{array}$} & $\begin{array}{l}\text { Integrated physicochemi- } \\
\text { cal process }\end{array}$ & High initial capital cost \\
\hline \multirow[t]{2}{*}{ Froth flotation } & & $\begin{array}{l}\text { Different types of collec- } \\
\text { tors (non-ionic or ionic) }\end{array}$ & Energy costs \\
\hline & & $\begin{array}{l}\text { Efficient for small particles } \\
\text { removal and can remove }\end{array}$ & $\begin{array}{l}\text { Maintenance and opera- } \\
\text { tion costs no negligible }\end{array}$ \\
\hline
\end{tabular}


Table 1.1 (continued)

\begin{tabular}{|c|c|c|c|}
\hline Process & $\begin{array}{l}\text { Main } \\
\text { characteristic(s) }\end{array}$ & Advantages & \multirow[t]{2}{*}{ Disadvantages } \\
\hline & & $\begin{array}{l}\text { low density particles } \\
\text { which would require long } \\
\text { settling periods }\end{array}$ & \\
\hline & & $\begin{array}{l}\text { Useful for primary } \\
\text { clarification }\end{array}$ & $\begin{array}{l}\text { Chemicals required } \\
\text { (to control the relative } \\
\text { hydrophobicities between } \\
\text { the particles and to main- } \\
\text { tain proper froth } \\
\text { characteristics) }\end{array}$ \\
\hline & & Metal selective & \multirow{4}{*}{$\begin{array}{l}\text { Selectivity is } \\
\text { pH-dependent }\end{array}$} \\
\hline & & Low retention time & \\
\hline & & $\begin{array}{l}\text { Used as an efficient ter- } \\
\text { tiary treatment in the pulp } \\
\text { and paper industry }\end{array}$ & \\
\hline & & $\begin{array}{l}\text { Mechanisms: true flota- } \\
\text { tion, entrainment, and } \\
\text { aggregation }\end{array}$ & \\
\hline $\begin{array}{l}\text { Chemical } \\
\text { oxidation }\end{array}$ & \multirow{12}{*}{$\begin{array}{l}\text { Use of an oxi- } \\
\text { dant (e.g. } \mathrm{O}_{3} \text {, } \\
\mathrm{Cl}_{2}, \mathrm{ClO}_{2}, \mathrm{H}_{2} \mathrm{O}_{2} \text {, } \\
\left.\mathrm{KMnO}_{4}\right)\end{array}$} & $\begin{array}{l}\text { Integrated physicochemi- } \\
\text { cal process }\end{array}$ & Chemicals required \\
\hline $\begin{array}{r}\text { Simple } \\
\text { oxidation }\end{array}$ & & $\begin{array}{l}\text { Simple, rapid and efficient } \\
\text { process }\end{array}$ & $\begin{array}{l}\text { Production, transport and } \\
\text { management of the oxi- }\end{array}$ \\
\hline Ozone & & & dants (other than ozone) \\
\hline $\begin{array}{l}\text { Hypochlorite } \\
\text { treatment }\end{array}$ & & $\begin{array}{l}\text { Generation of ozone } \\
\text { on-site (no storage- }\end{array}$ & $\begin{array}{l}\text { Pre-treatment } \\
\text { indispensable }\end{array}$ \\
\hline \multirow{8}{*}{$\begin{array}{l}\text { Hydrogen } \\
\text { peroxide }\end{array}$} & & associated dangers) & \\
\hline & & $\begin{array}{l}\text { Quality of the outflow } \\
\text { (effective destruction of } \\
\text { the pollutants, efficient } \\
\text { reduction of color) }\end{array}$ & $\begin{array}{l}\text { Efficiency strongly } \\
\text { influenced by the type of } \\
\text { oxidant }\end{array}$ \\
\hline & & $\begin{array}{l}\text { Good elimination of color } \\
\text { and odor (ozone) }\end{array}$ & Short half-life (ozone) \\
\hline & & $\begin{array}{l}\text { Efficient treatment for } \\
\text { cyanide and sulfide } \\
\text { removal }\end{array}$ & $\begin{array}{l}\text { A few dyes are more } \\
\text { resistant to treatment and } \\
\text { necessitate high ozone } \\
\text { doses }\end{array}$ \\
\hline & & $\begin{array}{l}\text { Initiates and accelerates } \\
\text { azo-bond cleavage (hypo- } \\
\text { chlorite treatment) }\end{array}$ & $\begin{array}{l}\text { Formation of (unknown) } \\
\text { intermediates }\end{array}$ \\
\hline & & $\begin{array}{l}\text { Increases biodegradability } \\
\text { of product }\end{array}$ & $\begin{array}{l}\text { No diminution of COD } \\
\text { values or limited effect } \\
\text { (ozone) }\end{array}$ \\
\hline & & High throughput & $\begin{array}{l}\text { No effect on salinity } \\
\text { (ozone) }\end{array}$ \\
\hline & & No sludge production & $\begin{array}{l}\text { Release of volatile com- } \\
\text { pounds and aromatic }\end{array}$ \\
\hline
\end{tabular}


Table 1.1 (continued)

\begin{tabular}{|c|c|c|c|}
\hline Process & $\begin{array}{l}\text { Main } \\
\text { characteristic(s) }\end{array}$ & Advantages & Disadvantages \\
\hline & & & $\begin{array}{l}\text { amines (hypochlorite } \\
\text { treatment) }\end{array}$ \\
\hline & & Possibility of water recycle & No effect on the COD \\
\hline & & $\begin{array}{l}\text { Disinfection (bacteria, } \\
\text { viruses) }\end{array}$ & Generates sludge \\
\hline $\begin{array}{l}\text { Biological } \\
\text { methods }\end{array}$ & \multirow{14}{*}{$\begin{array}{l}\text { Use of biological } \\
\text { (pure or mixed) } \\
\text { cultures }\end{array}$} & \multirow{5}{*}{$\begin{array}{l}\text { The application of micro- } \\
\text { organisms for the biodeg- } \\
\text { radation of organic } \\
\text { contaminants is simple, } \\
\text { economically attractive } \\
\text { and well accepted by the } \\
\text { public }\end{array}$} & \multirow{5}{*}{$\begin{array}{l}\text { Necessary to create an } \\
\text { optimally favorable } \\
\text { environment }\end{array}$} \\
\hline Bioreactors & & & \\
\hline $\begin{array}{l}\text { Biological } \\
\text { activated sludge } \\
\text { (BAS) }\end{array}$ & & & \\
\hline $\begin{array}{l}\text { Microbiologi- } \\
\text { cal treatments }\end{array}$ & & & \\
\hline $\begin{array}{c}\text { Enzymatic } \\
\text { decomposition }\end{array}$ & & & \\
\hline \multirow[t]{9}{*}{ Lagoon } & & $\begin{array}{l}\text { Large number of species } \\
\text { used in mixed cultures } \\
\text { (consortiums) or pure cul- } \\
\text { tures (white-rot fungus) }\end{array}$ & $\begin{array}{l}\text { Requires management } \\
\text { and maintenance of the } \\
\text { microorganisms and/or } \\
\text { physicochemical } \\
\text { pretreatment (inefficient } \\
\text { on non-degradable com- } \\
\text { pounds or when toxic } \\
\text { compounds are present) }\end{array}$ \\
\hline & & $\begin{array}{l}\text { White-rot fungi produce a } \\
\text { wide variety of extracellu- } \\
\text { lar enzymes with high } \\
\text { biodegradability capacity }\end{array}$ & $\begin{array}{l}\text { Slow process (problems } \\
\text { of kinetics) }\end{array}$ \\
\hline & & $\begin{array}{l}\text { Efficiently eliminates bio- } \\
\text { degradable organic matter, } \\
\mathrm{NH}_{3}, \mathrm{NH}_{4}^{+} \text {, iron }\end{array}$ & $\begin{array}{l}\text { Low biodegradability of } \\
\text { certain molecules (dyes) }\end{array}$ \\
\hline & & Attenuates color well & $\begin{array}{l}\text { Poor decolorization } \\
\text { (BAS) }\end{array}$ \\
\hline & & $\begin{array}{l}\text { High removal of BOD and } \\
\text { SS (BAS) }\end{array}$ & $\begin{array}{l}\text { Possible sludge bulking } \\
\text { and foaming (BAS) }\end{array}$ \\
\hline & & \multirow{4}{*}{$\begin{array}{l}\text { Decisive role of microbio- } \\
\text { logical processes in the } \\
\text { future technologies used } \\
\text { for the removal of emer- } \\
\text { gent contaminants from } \\
\text { waters }\end{array}$} & $\begin{array}{l}\text { Generation of biological } \\
\text { sludge and uncontrolled } \\
\text { degradation products }\end{array}$ \\
\hline & & & $\begin{array}{l}\text { The composition of mixed } \\
\text { cultures may change dur- } \\
\text { ing the decomposition } \\
\text { process }\end{array}$ \\
\hline & & & $\begin{array}{l}\text { Complexity of the micro- } \\
\text { biological mechanisms }\end{array}$ \\
\hline & & & $\begin{array}{l}\text { Necessity to have a good } \\
\text { knowledge of the enzy- } \\
\text { matic processes }\end{array}$ \\
\hline
\end{tabular}


Table 1.1 (continued)

\begin{tabular}{|c|c|c|c|}
\hline Process & $\begin{array}{l}\text { Main } \\
\text { characteristic(s) }\end{array}$ & Advantages & Disadvantages \\
\hline & & & $\begin{array}{l}\text { governing the decompo- } \\
\text { sition of the substances }\end{array}$ \\
\hline $\begin{array}{l}\text { Adsorption/ } \\
\text { filtration }\end{array}$ & $\begin{array}{l}\text { Non-destructive } \\
\text { process }\end{array}$ & $\begin{array}{l}\text { Technological simple } \\
\text { (simple equipment) and } \\
\text { adaptable to many treat- } \\
\text { ment formats }\end{array}$ & $\begin{array}{l}\text { Relatively high invest- } \\
\text { ment (CAC) }\end{array}$ \\
\hline CAC & \multirow{13}{*}{$\begin{array}{l}\text { Use of a solid } \\
\text { material }\end{array}$} & \multirow{2}{*}{$\begin{array}{l}\text { Large range of commercial } \\
\text { products }\end{array}$} & \multirow{2}{*}{$\begin{array}{l}\text { Cost of materials (CAC, } \\
\text { CAA) }\end{array}$} \\
\hline CAA & & & \\
\hline Sand & & \multirow{2}{*}{$\begin{array}{l}\text { Wide variety of target } \\
\text { contaminants (adsorption) }\end{array}$} & \multirow{2}{*}{$\begin{array}{l}\text { Non-destructive } \\
\text { processes }\end{array}$} \\
\hline $\begin{array}{r}\text { Mixed } \\
\text { materials }\end{array}$ & & & \\
\hline \multirow[t]{9}{*}{ Silica gel } & & $\begin{array}{l}\text { Highly effective process } \\
\text { (adsorption) with fast } \\
\text { kinetics } \\
\end{array}$ & Non-selective methods \\
\hline & & $\begin{array}{l}\text { Excellent quality of the } \\
\text { treated effluent }\end{array}$ & $\begin{array}{l}\text { Performance depends on } \\
\text { the type of materials } \\
\text { (CAC) }\end{array}$ \\
\hline & & $\begin{array}{l}\text { Global elimination (CAC) } \\
\text { but possibly selective } \\
\text { depending on adsorbent }\end{array}$ & $\begin{array}{l}\text { Requirement for several } \\
\text { types of adsorbent }\end{array}$ \\
\hline & & $\begin{array}{l}\text { Excellent ability to sepa- } \\
\text { rate a large range of pol- } \\
\text { lutants, in particular } \\
\text { refractory molecules (CAC } \\
\text { is the most effective } \\
\text { material) }\end{array}$ & $\begin{array}{l}\text { Chemical derivatization } \\
\text { to improve their adsorp- } \\
\text { tion capacity }\end{array}$ \\
\hline & & $\begin{array}{l}\text { CAC: efficient for COD } \\
\text { removal; highly efficient } \\
\text { treatment when coupled to } \\
\text { coagulation to reduce both } \\
\text { SS, COD and color }\end{array}$ & $\begin{array}{l}\text { Rapid saturation and } \\
\text { clogging of the reactors } \\
\text { (regeneration costly) }\end{array}$ \\
\hline & & $\begin{array}{l}\text { Sand: efficient for turbidity } \\
\text { and SS removal }\end{array}$ & $\begin{array}{l}\text { Not efficient with certain } \\
\text { types of dyestuffs and } \\
\text { some metals (CAC) }\end{array}$ \\
\hline & & \multirow[t]{3}{*}{$\begin{array}{l}\text { Alumina: efficient for } \\
\text { fluoride removal }\end{array}$} & $\begin{array}{l}\text { Elimination of the adsor- } \\
\text { bent (requires incinera- } \\
\text { tion, regeneration, or } \\
\text { replacement of the } \\
\text { material) }\end{array}$ \\
\hline & & & $\begin{array}{l}\text { Regeneration is expensive } \\
\text { and results in loss of } \\
\text { material (CAC) }\end{array}$ \\
\hline & & & $\begin{array}{l}\text { Economically non-viable } \\
\text { for certain industries }\end{array}$ \\
\hline
\end{tabular}


Table 1.1 (continued)

\begin{tabular}{|c|c|c|c|}
\hline \multirow[t]{2}{*}{ Process } & $\begin{array}{l}\text { Main } \\
\text { characteristic(s) }\end{array}$ & Advantages & Disadvantages \\
\hline & & & $\begin{array}{l}\text { (pulp and paper, } \\
\text { textile...) }\end{array}$ \\
\hline Ion-exchange & \multirow{13}{*}{$\begin{array}{l}\text { Non-destructive } \\
\text { process }\end{array}$} & \multirow{3}{*}{$\begin{array}{l}\text { Large range of commercial } \\
\text { products available from } \\
\text { several manufacturers }\end{array}$} & \multirow{3}{*}{$\begin{array}{l}\text { Economic constraints } \\
\text { (initial cost of the selec- } \\
\text { tive resin, maintenance } \\
\text { costs, regeneration time- } \\
\text { consuming...) }\end{array}$} \\
\hline $\begin{array}{l}\text { Chelating } \\
\text { resins }\end{array}$ & & & \\
\hline $\begin{array}{l}\text { Selective } \\
\text { resins }\end{array}$ & & & \\
\hline $\begin{array}{l}\text { Macroporous } \\
\text { resins }\end{array}$ & & \multirow[t]{2}{*}{$\begin{array}{l}\text { Technological simple } \\
\text { (simple equipment) }\end{array}$} & \multirow[t]{2}{*}{$\begin{array}{l}\text { Large volume requires } \\
\text { large columns }\end{array}$} \\
\hline $\begin{array}{l}\text { Polymeric } \\
\text { adsorbents }\end{array}$ & & & \\
\hline \multirow[t]{8}{*}{$\begin{array}{l}\text { Polymer-based } \\
\text { hybrid } \\
\text { adsorbents }\end{array}$} & & $\begin{array}{l}\text { Well established and tested } \\
\text { procedures; easy control } \\
\text { and maintenance }\end{array}$ & $\begin{array}{l}\text { Rapid saturation and } \\
\text { clogging of the reactors }\end{array}$ \\
\hline & & $\begin{array}{l}\text { Easy to use with other } \\
\text { techniques } \\
\text { (e.g. precipitation and fil- } \\
\text { tration in an integrated } \\
\text { wastewater process) }\end{array}$ & $\begin{array}{l}\text { Saturation of the cationic } \\
\text { exchanger before the } \\
\text { anionic resin (precipita- } \\
\text { tion of metals and } \\
\text { blocking of reactor) }\end{array}$ \\
\hline & & $\begin{array}{l}\text { Can be applied to different } \\
\text { flow regimes (continuous, } \\
\text { batch) }\end{array}$ & $\begin{array}{l}\text { Beads easily fouled by } \\
\text { particulates and organic } \\
\text { matter (organics, oils); } \\
\text { requires a physicochemi- } \\
\text { cal pretreatment (e.g. sand } \\
\text { filtration or carbon } \\
\text { adsorption) to remove } \\
\text { these contaminants }\end{array}$ \\
\hline & & $\begin{array}{l}\text { High regeneration with } \\
\text { possibility of external } \\
\text { regeneration of resin }\end{array}$ & $\begin{array}{l}\text { Matrix degrades with time } \\
\text { and with certain waste } \\
\text { materials (radioactive, } \\
\text { strong oxidants... ) }\end{array}$ \\
\hline & & Rapid and efficient process & $\begin{array}{l}\text { Performance sensitive to } \\
\mathrm{pH} \text { of effluent }\end{array}$ \\
\hline & & $\begin{array}{l}\text { Produce a high-quality } \\
\text { treated effluent }\end{array}$ & $\begin{array}{l}\text { Conventional resins not } \\
\text { selective }\end{array}$ \\
\hline & & $\begin{array}{l}\text { Concentrates all types of } \\
\text { pollutants, particularly } \\
\text { minerals }\end{array}$ & $\begin{array}{l}\text { Selective resins have lim- } \\
\text { ited commercial use }\end{array}$ \\
\hline & & $\begin{array}{l}\text { Relatively inexpensive and } \\
\text { efficient for metal removal; } \\
\text { clean-up to ppb levels } \\
\text { (to ppt levels for selective } \\
\text { resins) } \\
\text { Can be selective for certain } \\
\text { metals (with suitable } \\
\text { resins) }\end{array}$ & $\begin{array}{l}\text { Not effective for certain } \\
\text { target pollutants (disperse } \\
\text { dyes, drugs...) }\end{array}$ \\
\hline
\end{tabular}


Table 1.1 (continued)

\begin{tabular}{|c|c|c|c|}
\hline Process & $\begin{array}{l}\text { Main } \\
\text { characteristic(s) }\end{array}$ & Advantages & Disadvantages \\
\hline & & $\begin{array}{l}\text { Interesting and efficient } \\
\text { technology for the recov- } \\
\text { ery of valuable metals }\end{array}$ & Elimination of the resin \\
\hline Incineration & \multirow{5}{*}{$\begin{array}{l}\text { Destruction by } \\
\text { combustion }\end{array}$} & Simple process & Initial investment costs \\
\hline $\begin{array}{l}\text { Thermal } \\
\text { oxidation }\end{array}$ & & $\begin{array}{l}\text { Useful for concentrated } \\
\text { effluents or sludges }\end{array}$ & $\begin{array}{l}\text { Transport and storage of } \\
\text { the effluents }\end{array}$ \\
\hline $\begin{array}{l}\text { Catalytic } \\
\text { oxidation }\end{array}$ & & Highly efficient & High running costs \\
\hline \multirow[t]{2}{*}{$\begin{array}{l}\text { Photocatalytic } \\
\text { destruction }\end{array}$} & & $\begin{array}{l}\text { Eliminates all types of } \\
\text { organics }\end{array}$ & $\begin{array}{l}\text { Formation of dioxins and } \\
\text { others pollutants } \\
\text { (metals...) }\end{array}$ \\
\hline & & Production of energy & $\begin{array}{l}\text { Local communities } \\
\text { always have opposed the } \\
\text { presence of incinerating } \\
\text { plant in the locality }\end{array}$ \\
\hline Electrochemistry & \multirow[t]{12}{*}{ Electrolysis (E) } & \multirow{3}{*}{$\begin{array}{l}\text { Efficient technology for } \\
\text { the recovery/recycling of } \\
\text { valuable metals (E) }\end{array}$} & \multirow{3}{*}{$\begin{array}{l}\text { High initial cost of the } \\
\text { equipment }\end{array}$} \\
\hline Electrodeposition & & & \\
\hline $\begin{array}{l}\text { Electro-coagu- } \\
\text { lation (EC) }\end{array}$ & & & \\
\hline $\begin{array}{l}\text { Electro-floccu- } \\
\text { lation (EF) }\end{array}$ & & \multirow{4}{*}{$\begin{array}{l}\text { Adaptation to different } \\
\text { pollutant loads and differ- } \\
\text { ent flow rates (E) }\end{array}$} & \multirow[t]{4}{*}{$\begin{array}{l}\text { Cost of the maintenance } \\
\text { (sacrificial anodes...) }\end{array}$} \\
\hline $\begin{array}{l}\text { Electro- } \\
\text { flotation }\end{array}$ & & & \\
\hline Electrooxidation & & & \\
\hline $\begin{array}{l}\text { Electrochemi- } \\
\text { cal oxidation }\end{array}$ & & & \\
\hline $\begin{array}{l}\text { Electrochemi- } \\
\text { cal reduction }\end{array}$ & & \multirow{2}{*}{$\begin{array}{l}\text { More effective and rapid } \\
\text { organic matter separation } \\
\text { than in traditional coagu- } \\
\text { lation (EC) }\end{array}$} & \multirow{2}{*}{$\begin{array}{l}\text { Requires addition of } \\
\text { chemicals (coagulants, } \\
\text { flocculants, salts) }\end{array}$} \\
\hline Cementation & & & \\
\hline $\begin{array}{l}\quad \text { Indirect } \\
\text { electro-oxidation } \\
\text { with strong } \\
\text { oxidants }\end{array}$ & & \multirow[t]{2}{*}{$\begin{array}{l}\text { Efficient elimination of SS, } \\
\text { oils, greases, color and } \\
\text { metals (EC, EF) }\end{array}$} & \multirow{2}{*}{$\begin{array}{l}\text { Anode passivation and } \\
\text { sludge deposition on the } \\
\text { electrodes that can inhibit } \\
\text { the electrolytic process in } \\
\text { continuous operation }\end{array}$} \\
\hline \multirow{2}{*}{$\begin{array}{l}\text { Photo-assisted } \\
\text { electrochemical } \\
\text { methods }\end{array}$} & & & \\
\hline & & $\begin{array}{l}\text { EC: pH control is not nec- } \\
\text { essary; generation of } \\
\text { coagulants in situ; eco- } \\
\text { nomically feasible and } \\
\text { very effective in removing } \\
\text { suspended solids, } \\
\text { dissolved metals, tannins } \\
\text { and dyes (effluents from } \\
\text { textile, catering, petro- } \\
\text { leum, municipal sewage, }\end{array}$ & $\begin{array}{l}\text { Requires post-treatment } \\
\text { to remove high concen- } \\
\text { trations of iron and alu- } \\
\text { minum ions }\end{array}$ \\
\hline
\end{tabular}


Table 1.1 (continued)

\begin{tabular}{|c|c|c|c|}
\hline \multirow[t]{8}{*}{ Process } & $\begin{array}{l}\text { Main } \\
\text { characteristic(s) }\end{array}$ & Advantages & Disadvantages \\
\hline & & $\begin{array}{l}\text { oil-water emulsion, } \\
\text { dye-stuff, clay } \\
\text { suspension...) }\end{array}$ & \\
\hline & & $\begin{array}{l}\text { EF: Widely used in the } \\
\text { miming industries }\end{array}$ & $\begin{array}{l}\text { EF: Separation efficiency } \\
\text { depends strongly on bub- } \\
\text { ble sizes }\end{array}$ \\
\hline & & $\begin{array}{l}\text { Effective in treatment of } \\
\text { drinking water supplies for } \\
\text { small or medium sized } \\
\text { communities (EC) }\end{array}$ & Filtration process for flocs \\
\hline & & $\begin{array}{l}\text { Interesting method for the } \\
\text { recovery of gold and silver } \\
\text { from rinse baths (E) }\end{array}$ & $\begin{array}{l}\text { Formation of sludge (fil- } \\
\text { tering problems) }\end{array}$ \\
\hline & & $\begin{array}{l}\text { Very effective treatment } \\
\text { for the reduction, coagula- } \\
\text { tion and separation of } \\
\text { copper (EC) }\end{array}$ & $\begin{array}{l}\text { Cost of sludge treatment } \\
\text { (electro-coagulation) }\end{array}$ \\
\hline & & $\begin{array}{l}\text { Increases biodegradabil- } \\
\text { ity (E) }\end{array}$ & \\
\hline & & $\begin{array}{l}\text { Cementation: Efficient for } \\
\text { copper removal }\end{array}$ & \\
\hline $\begin{array}{l}\text { Membrane } \\
\text { filtration }\end{array}$ & \multirow[t]{3}{*}{$\begin{array}{l}\text { Non-destructive } \\
\text { separation }\end{array}$} & \multirow{3}{*}{$\begin{array}{l}\text { Large range of commercial } \\
\text { membrane available from } \\
\text { several manufacturers; } \\
\text { large number of applica- } \\
\text { tions and module } \\
\text { configurations }\end{array}$} & \multirow{3}{*}{$\begin{array}{l}\text { Investment costs are often } \\
\text { too high for small and } \\
\text { medium industries }\end{array}$} \\
\hline $\begin{array}{l}\text { Microfiltration } \\
\text { (MF) }\end{array}$ & & & \\
\hline $\begin{array}{l}\text { Ultrafiltration } \\
\text { (UF) }\end{array}$ & & & \\
\hline $\begin{array}{l}\text { Nanofiltration } \\
\text { (NF) }\end{array}$ & \multirow[t]{9}{*}{$\begin{array}{l}\text { Semi-permeable } \\
\text { barrier }\end{array}$} & \multirow[t]{6}{*}{ Small space requirement } & \multirow[t]{6}{*}{ High energy requirements } \\
\hline $\begin{array}{l}\text { Reverse osmo- } \\
\text { sis (RO) }\end{array}$ & & & \\
\hline Dialysis (D) & & & \\
\hline $\begin{array}{l}\text { Electrodialysis } \\
\text { (ED) }\end{array}$ & & & \\
\hline $\begin{array}{l}\text { Electroelectro- } \\
\text { dialysis (EED) }\end{array}$ & & & \\
\hline $\begin{array}{l}\text { Emulsion liq- } \\
\text { uid membranes } \\
\text { (ELM) }\end{array}$ & & & \\
\hline \multirow[t]{3}{*}{$\begin{array}{l}\text { Supported liq- } \\
\text { uid membranes } \\
\text { (SLM) }\end{array}$} & & $\begin{array}{l}\text { Simple, rapid and efficient, } \\
\text { even at high } \\
\text { concentrations }\end{array}$ & $\begin{array}{l}\text { The design of membrane } \\
\text { filtration systems can dif- } \\
\text { fer significantly }\end{array}$ \\
\hline & & $\begin{array}{l}\text { Produces a high-quality } \\
\text { treated effluent }\end{array}$ & $\begin{array}{l}\text { High maintenance and } \\
\text { operation costs }\end{array}$ \\
\hline & & No chemicals required & \\
\hline
\end{tabular}


Table 1.1 (continued)

\begin{tabular}{|c|c|c|c|}
\hline Process & $\begin{array}{l}\text { Main } \\
\text { characteristic(s) }\end{array}$ & Advantages & Disadvantages \\
\hline & & & $\begin{array}{l}\text { Rapid membrane clogging } \\
\text { (fouling with high } \\
\text { concentrations) }\end{array}$ \\
\hline & & $\begin{array}{l}\text { Low solid waste } \\
\text { generation }\end{array}$ & Low throughput \\
\hline & & $\begin{array}{l}\text { Eliminates all types of } \\
\text { dyes, salts and mineral } \\
\text { derivatives }\end{array}$ & Limited flow rates \\
\hline & & $\begin{array}{l}\text { Efficient elimination of } \\
\text { particles, SS and micro- } \\
\text { organisms (MF, UF, NF, } \\
\text { RO), volatile and } \\
\text { non-volatile organics (NF, } \\
\text { RO), dissolved inorganic } \\
\text { matter (ED, EED), and } \\
\text { phenols, cyanide and zinc } \\
\text { (ELM) }\end{array}$ & $\begin{array}{l}\text { Not interesting at low } \\
\text { solute feed concentrations }\end{array}$ \\
\hline & & $\begin{array}{l}\text { Possible to be metal } \\
\text { selective }\end{array}$ & $\begin{array}{l}\text { The choice of the mem- } \\
\text { brane is determined by the } \\
\text { specific application (hard- } \\
\text { ness reduction, particulate } \\
\text { or TOC removal, potable } \\
\text { water production...) }\end{array}$ \\
\hline & & $\begin{array}{l}\text { A wide range of real } \\
\text { applications: clarification } \\
\text { or sterile filtration (MF), } \\
\text { separation of polymers } \\
\text { (UF), multivalents ions } \\
\text { (NF), salts from polymer } \\
\text { solutions (D) and } \\
\text { non-ionic solutes (ED), } \\
\text { desalination and produc- } \\
\text { tion of pure water (RO) }\end{array}$ & Specific processes \\
\hline & & $\begin{array}{l}\text { Well-known separation } \\
\text { mechanisms: Size- } \\
\text { exclusion (NF, UF, MF), } \\
\text { solubility/diffusivity (RO, } \\
\text { pervaporation), charge } \\
\text { (electrodialysis) }\end{array}$ & $\begin{array}{l}\text { Elimination of the } \\
\text { concentrate }\end{array}$ \\
\hline \multirow[t]{2}{*}{ Evaporation } & $\begin{array}{l}\text { Concentration } \\
\text { technique }\end{array}$ & $\begin{array}{l}\text { Several types of evapora- } \\
\text { tors exist on the market }\end{array}$ & $\begin{array}{l}\text { Expensive costs for high } \\
\text { volumes of wastewater } \\
\text { (energy consumption, } \\
\text { volume of the concentrate } \\
\text { and costs of disposal) }\end{array}$ \\
\hline & Thermal process & $\begin{array}{l}\text { Versatile technique (the } \\
\text { number of cells can be }\end{array}$ & $\begin{array}{l}\text { Investment costs are often } \\
\text { too high for small and } \\
\text { medium industries }\end{array}$ \\
\hline
\end{tabular}


Table 1.1 (continued)

\begin{tabular}{|c|c|c|c|}
\hline Process & $\begin{array}{l}\text { Main } \\
\text { characteristic(s) }\end{array}$ & Advantages & Disadvantages \\
\hline & & $\begin{array}{l}\text { adapted to the required } \\
\text { evaporation capacity) }\end{array}$ & \\
\hline \multirow[t]{5}{*}{$\begin{array}{l}\text { Membrane } \\
\text { pervaporation } \\
(\mathrm{MPV})\end{array}$} & \multirow[t]{5}{*}{$\begin{array}{l}\text { Separation } \\
\text { process }\end{array}$} & $\begin{array}{l}\text { The energy-costs are well- } \\
\text { known for the different } \\
\text { configurations }\end{array}$ & $\begin{array}{l}\text { High pollution load in the } \\
\text { concentrates }\end{array}$ \\
\hline & & Efficient processes & $\begin{array}{l}\text { Crystallization due to the } \\
\text { concentration of the } \\
\text { wastewater and corrosion } \\
\text { of the heating elements in } \\
\text { the evaporator due to the } \\
\text { chemical aggressiveness } \\
\text { of the concentrated } \\
\text { effluent }\end{array}$ \\
\hline & & $\begin{array}{l}\text { Interesting for the produc- } \\
\text { tion of water for rinsing } \\
\text { operations (recycling of } \\
\text { distillates), the concentra- } \\
\text { tion of rinsing effluents for } \\
\text { re-introduction into the } \\
\text { process and for the purifi- } \\
\text { cation of treatment baths } \\
\text { (to maintain their nominal } \\
\text { concentration) }\end{array}$ & $\begin{array}{l}\text { Problem with the evapo- } \\
\text { ration of effluents } \\
\text { containing free cyanide }\end{array}$ \\
\hline & & $\begin{array}{l}\text { Also interesting for the } \\
\text { separation of phenol by } \\
\text { steam distillation }\end{array}$ & $\begin{array}{l}\text { Requires the installation } \\
\text { of a cleaning circuit } \\
\text { (to prevent atmospheric } \\
\text { pollution) }\end{array}$ \\
\hline & & $\begin{array}{l}\text { MPV: a quite recent tech- } \\
\text { nology applied to the } \\
\text { removal of organics from } \\
\text { water }\end{array}$ & $\begin{array}{l}\text { Potential contamination } \\
\text { of the distillate preventing } \\
\text { reuse (due to the presence } \\
\text { of some VOC or hydro- } \\
\text { carbons in the effluent) }\end{array}$ \\
\hline $\begin{array}{l}\text { Liquid-liquid } \\
\text { (solvent) } \\
\text { extraction }\end{array}$ & $\begin{array}{l}\text { Separation } \\
\text { technology }\end{array}$ & $\begin{array}{l}\text { A well-known established } \\
\text { separation technology for } \\
\text { wastewater recycling }\end{array}$ & $\begin{array}{l}\text { High investment } \\
\text { (equipment) }\end{array}$ \\
\hline \multirow[t]{4}{*}{$\begin{array}{l}\text { Membrane- } \\
\text { based solvent } \\
\text { extraction }\end{array}$} & \multirow[t]{4}{*}{$\begin{array}{l}\text { Solvent } \\
\text { extraction }\end{array}$} & $\begin{array}{l}\text { Principally used for large- } \\
\text { scale operations where the } \\
\text { load of contaminants are } \\
\text { high }\end{array}$ & $\begin{array}{l}\text { Uneconomic when con- } \\
\text { taminant concentrations } \\
\text { are low }(<0.5 \mathrm{~g} / \mathrm{L})\end{array}$ \\
\hline & & $\begin{array}{l}\text { Extraction/stripping opera- } \\
\text { tions easy to perform }\end{array}$ & $\begin{array}{l}\text { Use of large volumes of } \\
\text { organic extractants }\end{array}$ \\
\hline & & $\begin{array}{l}\text { Simple control and moni- } \\
\text { toring of process }\end{array}$ & $\begin{array}{l}\text { Use of potential toxic } \\
\text { solvents }\end{array}$ \\
\hline & & $\begin{array}{l}\text { Economically viable when } \\
\text { both solute concentrations } \\
\text { and wastewater flowrates } \\
\text { are high }\end{array}$ & $\begin{array}{l}\text { Not interesting at low } \\
\text { solute feed concentrations }\end{array}$ \\
\hline
\end{tabular}


Table 1.1 (continued)

\begin{tabular}{|c|c|c|c|}
\hline Process & $\begin{array}{l}\text { Main } \\
\text { characteristic(s) }\end{array}$ & Advantages & Disadvantages \\
\hline & & $\begin{array}{l}\text { Relatively low operating } \\
\text { costs }\end{array}$ & $\begin{array}{l}\text { Hydrodynamic constraints } \\
\text { (flooding, entrainment) }\end{array}$ \\
\hline & & $\begin{array}{l}\text { Recyclability of } \\
\text { extractants }\end{array}$ & $\begin{array}{l}\text { Entrainment of phases } \\
\text { giving poor effluent } \\
\text { quality }\end{array}$ \\
\hline & & $\begin{array}{l}\text { Selectivity of the } \\
\text { exchangers for metals effi- } \\
\text { cient for metal removal } \\
\text { (cations, anions, ion pairs) }\end{array}$ & $\begin{array}{l}\text { Possible cross- } \\
\text { contamination of the } \\
\text { aqueous stream }\end{array}$ \\
\hline & & $\begin{array}{l}\text { Efficient for the separation } \\
\text { of phenol }\end{array}$ & $\begin{array}{l}\text { Emulsification of phase } \\
\text { with poor separation }\end{array}$ \\
\hline & & $\begin{array}{l}\text { A good alternative to clas- } \\
\text { sical lime precipitation for } \\
\text { phosphoric acid } \\
\text { recuperation }\end{array}$ & $\begin{array}{l}\text { Fire risk from use of } \\
\text { organic solvents and } \\
\text { VOC emissions }\end{array}$ \\
\hline $\begin{array}{l}\text { Advanced oxida- } \\
\text { tion processes } \\
\text { (AOP) }\end{array}$ & $\begin{array}{l}\text { Emerging } \\
\text { processes }\end{array}$ & $\begin{array}{l}\text { In situ production of reac- } \\
\text { tive radicals }\end{array}$ & Laboratory scale \\
\hline Photolysis & \multirow{11}{*}{$\begin{array}{l}\text { Destructive } \\
\text { techniques }\end{array}$} & \multirow{4}{*}{$\begin{array}{l}\text { Little or no consumption } \\
\text { of chemicals }\end{array}$} & \multirow{4}{*}{$\begin{array}{l}\text { Economically non-viable } \\
\text { for small and medium } \\
\text { industries }\end{array}$} \\
\hline $\begin{array}{l}\quad \text { Heterogeneous } \\
\text { and homoge- } \\
\text { neous } \\
\text { photocatalytic } \\
\text { reactions }\end{array}$ & & & \\
\hline $\begin{array}{l}\text { Non catalytic } \\
\text { wet air oxidation } \\
\text { (WAO) } \\
\end{array}$ & & & \\
\hline $\begin{array}{l}\text { Catalytic wet } \\
\text { air oxidation } \\
\text { (CWAO) }\end{array}$ & & & \\
\hline \multirow[t]{7}{*}{$\begin{array}{c}\text { Supercritical } \\
\text { water gasification }\end{array}$} & & $\begin{array}{l}\text { Mineralization of the } \\
\text { pollutants }\end{array}$ & Technical constraints \\
\hline & & No production of sludge & Formation of by-products \\
\hline & & Rapid degradation & Low throughput \\
\hline & & $\begin{array}{l}\text { Efficient for recalcitrant } \\
\text { molecules (dyes, drugs...) }\end{array}$ & $\begin{array}{l}\text { High-pressure and } \\
\text { energy-intensive condi- } \\
\text { tions (WAO) }\end{array}$ \\
\hline & & $\begin{array}{l}\text { Very good abatement of } \\
\text { COD and TOC }\end{array}$ & $\begin{array}{l}\text { pH-dependence } \\
\text { (in particular for WAO) }\end{array}$ \\
\hline & & $\begin{array}{l}\text { WAO: technology suitable } \\
\text { for effluent too dilute for } \\
\text { incineration and too toxic } \\
\text { and/or concentrated for } \\
\text { biological treatment }\end{array}$ & \multirow[t]{2}{*}{$\begin{array}{l}\text { WAO: completed miner- } \\
\text { alization not achieved }\end{array}$} \\
\hline & & $\begin{array}{l}\text { Destruction of phenol in } \\
\text { water solution: WAO, } \\
\text { CWAO }\end{array}$ & \\
\hline
\end{tabular}


Table 1.1 (continued)

\begin{tabular}{l|l|l|l}
\hline Process & $\begin{array}{l}\text { Main } \\
\text { characteristic(s) }\end{array}$ & Advantages & Disadvantages \\
\hline & & $\begin{array}{l}\text { Insoluble organic matter } \\
\text { is converted to simpler } \\
\text { soluble compounds with- } \\
\text { out emissions of danger- } \\
\text { ous substances (WAO) }\end{array}$ & \\
& & \\
\hline
\end{tabular}

Viraraghavan 2004; Parsons 2004; Forgacs et al. 2004; Anjaneyulu et al. 2005; Chuah et al. 2005; Crini 2005, 2006; Bratby 2006; Crini and Badot 2007, 2010; Cox et al. 2007; Mohan and Pittman 2007; Hai et al. 2007; Wojnárovits and Takács 2008; Barakat 2011; Sharma and Sanghi 2012; Rathoure and Dhatwalia 2016; Morin-Crini and Crini 2017).

Selection of the method to be used will thus depend on the wastewater characteristics (Anjaneyulu et al. 2005; Crini 2005; Crini and Badot 2007; Cox et al. 2007). Each treatment has its own constraints not only in terms of cost, but also in terms of feasibility, efficiency, practicability, reliability, environmental impact, sludge production, operation difficulty, pre-treatment requirements and the formation of potentially toxic byproducts. However, among the various treatment processes currently cited for wastewater treatment, only a few are commonly employed by the industrial sector for technological and economic reasons. In general, removal of pollutants from effluents is done by physicochemical and/or biological means, with research concentrating on cheaper effective combinations of systems or new alternatives.

\subsection{Conclusion}

The development of cheaper, effective and novel methods of decontamination is currently an active field of research, as shown by the numerous publications appearing each year. Preserving the environment, and in particular the problem of water pollution, has become a major preoccupation for everyone - the public, industry, scientists and researchers as well as decision-makers on a national, European, or international level. The public demand for pollutant-free waste discharge to receiving waters has made decontamination of industrial wastewaters a top priority. However, this is a difficult and challenging task (Sonune and Ghate 2004; Anjaneyulu et al. 2005; Barakat 2011; Sharma and Sanghi 2012). It is also difficult to define a universal method that could be used for the elimination of all pollutants from wastewaters. This chapter described the advantages and disadvantages of technologies available. A multitude of techniques classified in conventional methods, established recovery processes and emerging removal methods can be used. However, among the numerous and various treatment processes currently cited for wastewater treatment, only a few are commonly used by the industrial 
sector for economic and technological reasons. Adsorption onto activated carbons is nevertheless often cited as the procedure of choice to remove many different types of pollutants because it gives the best results in terms of efficiency and technical feasibility at the industrial scale.

\section{References}

Amiard JC (2011) Les risques chimiques environnementaux. Editions TEC \& DOC Lavoisier, Paris, 782 p (in French)

Anjaneyulu Y, Sreedhara Chary N, Samuel Suman Raj D (2005) Decolourization of industrial effluents - available methods and emerging technologies - a review. Rev Environ Sci Biotechnol 4:245-273. https://doi.org/10.1007/s11157-005-1246-z

Barakat MA (2011) New trends in removing heavy metals from industrial wastewater. Arab J Chem 4:361-377. https://doi.org/10.1016/j.arabjc.2010.07.019

Berefield LD, Judkins JF, Weand BL (1982) Process chemistry for water and wastewater treatment. Prentice-Hall, Englewood Cliffs, 510 p

Bratby J (2006) Coagulation and flocculation in water and wastewater treatment. IWA Publishing, London, p 407

Chen G (2004) Electrochemical technologies in wastewater treatment. Sep Purif Technol 38:11-41. https://doi.org/10.1016/j.seppur.2003.10.006

Chuah TG, Jumasiah A, Azni I, Katayon S, Choong SYT (2005) Rice husk as a potentially low-cost biosorbent for heavy metal and dye removal: an overview. Desalination 175:305-316. https:// doi.org/10.1016/j.desal.2004.10.014

Cooney DO (1999) Adsorption design for wastewater treatment. Lewis Publishers, Boca Raton, $208 \mathrm{p}$

Cooper P (1993) Removing colour from dye house waste waters - a critical review of technology available. J Soc Dyers Colour 109:97-100. https://doi.org/10.1111/j.1478-4408.1993.tb01536. $\mathrm{x}$

Cox M, Négré P, Yurramendi L (2007) Industrial liquid effluents. INASMET Tecnalia, San Sebastian, p 283

Crini G (2005) Recent developments in polysaccharide-based materials used as adsorbents in wastewater treatment. Prog Polym Sci 30:38-70. https://doi.org/10.1016/j.progpolymsci.2004. 11.002

Crini G (2006) Non-conventional low-cost adsorbents for dye removal. Bioresour Technol 97:1061-1085. https://doi.org/10.1016/j.biortech.2005.05.001

Crini G, Badot PM (2007) Traitement et épuration des eaux industrielles polluées. PUFC, Besançon, $353 \mathrm{p}$ (in French)

Crini G, Badot PM (eds) (2010) Sorption processes and pollution. PUFC, Besançon, $489 \mathrm{p}$

Druart C, Morin-Crini N, Euvrard E, Crini G (2016) Chemical and ecotoxicological monitoring of discharge water from a metal-finishing factory. Environ Process 3:59-72. https://doi.org/10. 1007/s40710-016-0125.7

Forgacs E, Cserhati T, Oros G (2004) Removal of synthetic dyes from wastewaters: a review. Environ Int 30:953-971. https://doi.org/10.1016/j.envint.2004.02.001

Hai FI, Yamamoto K, Fukushi K (2007) Hybrid treatment systems for dye wastewater. Crit Rev Environ Sci Technol 37:315-377. https://doi.org/10.1080/10643380601174723

Harvey PJ, Campanella BF, Castro PM, Harms H, Lichtfouse E, Schäffner AR, Smrcek S, WerckReichhart D (2002) Phytoremediation of polyaromatic hydrocarbons, anilines and phenols. Environ Sci Pollut Res Int 9:29-47

Henze M (ed) (2001) Wastewater treatment - biological and chemical processes. Springer, Berlin/New York 
Kentish SE, Stevens GW (2001) Innovations in separations technology for the recycling and re-use of liquid waste streams. Chem Eng J 84:149-159

Khalaf MN (2016) Green polymers and environmental pollution control. CRC Press; Apple Academic Press, Inc, Oakville, $436 \mathrm{p}$

Lacorte S, Latorre A, Barcelo D, Rigol A, Malqvist A, Welander T (2003) Organic compounds in paper-mill process waters and effluents. Trends Anal Chem 22:725-737

Liu DHF, Liptak BG (eds) (2000) Wastewater treatment. CRC Press, Boca Raton

Mohan D, Pittman CU (2007) Arsenic removal from waste/wastewater using adsorbents - a critical review. J Hazard Mater 142:1-53. https://doi.org/10.1016/j.jhazmat.2007.01.006

Morin-Crini N, Crini G (eds) (2017) Eaux industrielles contaminées. PUFC, Besançon, 513 p (in French)

Parsons S (ed) (2004) Advanced oxidation process for water and wastewater treatment. Editions IWA Publishing, London

Pokhrel D, Viraraghavan T (2004) Treatment of pulp and paper mill wastewater - a review. Sci Total Technol 333:37-58. https://doi.org/10.1016/j.scitotenv.2004.05.017

Rana T, Gupta S, Kumar D, Sharma S, Rana M, Rathore VS, Pereira BMJ (2004) Toxic effects of pulp and paper-mill effluents on male reproductive organs and some systemic parameters in rats. Environ Toxicol Pharmacol 18:1-7. https://doi.org/10.1016/j.etap.2004.04.005

Rathoure AK, Dhatwalia VK (2016) Toxicity and waste management using bioremediation. IGI Global, Hershey, $421 \mathrm{p}$

Sharma SK (2015) Green chemistry for dyes removal from wastewater. Scrivener Publishing LLC Wiley, Beverley, $496 \mathrm{p}$

Sharma SK, Sanghi R (2012) Advances in water treatment and pollution prevention. Springer, Dordrecht, $457 \mathrm{p}$

Sonune A, Ghate R (2004) Developments in wastewater treatment methods. Desalination 167:55-63. https://doi.org/10.1016/j.desal.2004.06.113

Wojnárovits L, Takács E (2008) Irradiation treatment of azo dye containing wastewater: an overview. Rad Phys Chem 77:225-244. https://doi.org/10.1016/j.radphyschem.2007.05.003 